\title{
The Pressure of Society Faced by Women in Miller's All My Sons
}

\author{
Dr.Itishri Sarangi \\ Assistant Professor KIIT University, Bhubaneswar
}

\begin{abstract}
Society and culture has always affected and influenced women. The feminist thinking finds difficult to argue on such thinking. Despite multiple versions of feminist criticism that began to emerge in the mid-twentieth century, Miller's play seems hardly concerned with the women's assertion of distinct identity in societal order. The presence of women appears apparently marginal as they only serve the dramatic purpose of complimenting and enriching the plot as well as reinforcing Miller's artistic vision.
\end{abstract}

Miller took almost two years to write All My Sons, which was the longest time he took to write a play. "Thus, as in Ibsen's best known work, a great amount of time is taken up with bringing the past into the present" ("Introduction" 20). The inspiration of the play All My Sons came from a wartime anecdote Miller heard about a woman, who had deserted in her father for delivering defective equipment to the U.S Military. From this Miller shaped the drama not about war, but about a topic, he knew better: money. The play is based on a true story. All My Sons happened to strike in Miller's mind after a casual conversation. "During an idle chat in my living room, a pious lady from the Middle West told of a family in the neighborhood which had been destroyed when the daughter turned the father into the authorities on discovering that he had been selling faulty machinery to the Army. The war was then in full blast. By the time she had finished the tale I had transferred the daughter into a son..." (Introduction 17). Arthur Miller's then mother-in-law pointed out in an Ohio newspaper, "The play's force lies in Miller's portrayal of how its characters come to identify and reckon with the sources of this unease, as what initially appears as a sunny small-town idyll turns dark and stormy"(Brantley's review online). All My Sons won the Drama Critic Circle Award beating Eugene O'Neill's work The Iceman's Cometh. With the success of All My Sons Miller says, I had won a new freedom to create, and I would stand on the high point of the Bridge's arch facing the wind from the ocean, trying to embrace a world larger than I had been able to conceive of until this time(...) The problem with All My Sons was not that it was too realistic but that it left too little space and time for the wordless darkness that underlies all verbal truth" (Timebends 144).

The play's original title was The Sign of the Archer. Miller says that "In its earlier version, the mother, Kate Keller was in a dominating position; more precisely her astrological beliefs were given great prominence." Miller justifies the change of the title, "where in previous play I might well have been satisfied to create only an astrologically obsessed woman, the obsession now had to be opened up to reveal its core of self-interest and intention on the character's part" ("Introduction" 20). The play focuses on Joe Keller and his sons; Miller recalls two productions of the play in Israel (1977) and a few years later in London. "The play in this production was centered on Kate, the mother, which was an emphasis our original production had bypassed in favor of the father-son conflict(...) Her guilty knowledge, so obdurately and menacingly suppressed, can be interpreted as her wish to deny her son's death also, and perhaps even primarily, to take vengeance on her culpable husband driving to his knees and ultimately to suicide" (Timebends 135).

The protagonist in Miller's plays always searches for an identity and the woman close to him helps him in achieving it. The woman protects him from the truth that might destroy him and at the same time helps him to see the truth. Kate's stubborn refusal to accept Larry's death is perhaps the strong point in the play and the play revolves around it. The story of every woman in the plays of Miller is that of a common woman trapped by the commonplace values and pressures of the society. She is always a marginal figure in the play. Kate in All My Sons and Linda in The Death of a Salesman are not only loyal and subservient wives but also their attitude seems to sum up many traditional American values. Both Linda's and Kate's role in society is extremely limited. They are admirable figures, fulfilling the role of wife and mother and, an ideal American wife supporting their husband.

Miller introduces Kate Keller in these words: "Mother appears on porch, she is in her early fifties, a woman of uncontrolled inspiration and an overwhelming capacity of love" (Act 1, 16). Kate is presented to us as a disturbed mother, who waits for his son Larry to come back from war. The memorial apple tree planted in the 
name of Larry toppled away by the wind. Kate's reaction to the blown apple tree is superstitious and oversensitive. Miller even builds up a fearful expectancy about Kate's reactions to it.

Mother: I was fast asleep, and (...) Remember the way he used to fly low past the house when he was in the training? When we used to see his face in the cockpit going by? That's the way I saw him. Only high up. Way, way up, where the clouds are. He was so real I could reach out and touch him. And suddenly he started to fall. And crying, crying to me(...)Mom, Mom! I could hear him like he was in the room. Mom!(...)it was his voice! If I could touch him I knew I could stop him, if I could only... I woke up and it was so funny- The wind(...) it was like the roaring of his engine. I came out here(...)I must've still been asleep. I could hear that roaring like he was going by. The tree snapped right in front of me-and I like-came awake (...) See? We should never have planted that tree. I said so in the first place; it was too soon to plant a tree for him.

Chris (alarmed): Too soon! (... ) Mother, Mother! The wind blew it down. What significance has that got? What are you talking about? Mother, please...don't go through it all again, will u? It's no good, it doesn't accomplish anything. I've been thinking, y'know? — maybe we ought to put our minds forgetting him?

Mother: That's the third time you've said that this week.

Chris: Because it's not right: we never took up our lives again. We're like at a railroad station waiting for a train that never comes in (Act-1, 19).

Kate throughout the play protects Joe and others from the truth. The truth she hides for about three and a half years is that a father is responsible for his son's death. She holds the truth for a long time, as intuitively as she knows her husband's guilt. Kate's belief that Larry is alive is based on a strange logic. As she asserts to Chris, "Your brother's alive, darling, because if he's dead your father killed him. Do you understand me now? As long as you live, that boy is alive. God does not let a son be killed by his father. Now you see don't you? Now you see" (73). Kate suffers no great shocks at Ann's letter unlike Martha in Edward Albee's Who's Afraid of Virginia Woolf, who learns about the death of her son. What mattered was that no one said it aloud. In Martha, what truly died was not the son but the mother's self-deception. For Kate the guilt of her husband is the source of her anxieties and headaches throughout the play.

Joe's response to it is ironic "She's out of her mind" (73). Kate's obsession deepens after Ann returns on an invitation by Chris. She opposes the possible alliance between Ann and Chris. Kate perceives Ann to be "Larry's girl." (72) Kate protects Chris from marrying Ann because she's "Larry's girl." Joe warns Chris that if he does so it will destroy Kate's dream that Larry will return one day. Hiding the truth of Joe's guilt makes her ill, resulting in her nervous breakdown twice, and Dr. Jim Bayliss expresses concern for her health. Her incapacity to accept the fact prompts Kate to ask her neighbor, Frank, to determine Larry's horoscope for the day he died.

In the whole play, Kate is the only woman in the house hoping for Larry's return even after he has been missing three years and she is the one who is constantly talking about Larry. On the arrival of George, Kate advises Joe, "Be smart Joe" (41) and asks Chris to protect George from questioning his father. She appeals Chris at the start of Act II, "We're dumb; Chris, Dad and I are stupid people. We don't know anything. You've got to protect us" (Act 2, 42). While Kate is pleading Chris to save them Joe on the other hand sleeps soundly.

Kate tells Chris, "If they are going to open the case I won't live through it" (42). Act II reopens, as twilight falls. The twilight is symbolic. Keller's end is coming nearer. Joe Keller sleeping suggests his agony and mental illness, which he hides. The dialogues of Kate in the opening of Act II show her fear and sadness as she visualizes 'an impending disaster'. She tries to bring all things before Chris. She fears, "what can be the intensity of human agony when everything is realized?" The truth might blast the family. As Hayman aptly remarks, "Her stupidity and her stubborn superstitiousness come almost to seem like a dignified refusal to be bound by the norms of reasonableness" (18).

Keller's integrity is questioned after the revelation of the letter of Larry, which he wrote just before his death. Kate's casual remark, a supposed slip of tongue that her husband has not been sick for fifteen years leads to the discovery of Joe's lie. At last, Joe realizes that Larry's letter had made him a stranger in his own house. However, at the end of the play, Kate prompts Joe's purge of conscience.

When Frank arrives home with the horoscope that prompts Chris to state his intentions of marrying Ann, Kate shouts, "Never, Never" (72). Kate admits Joe's guilt prodded by Jim having guessed it. Joe wants to talk to Ann. While Kate says, "You can't bull yourself through this one Joe (...) I have no strength to think anymore (...) All your life whenever there is trouble you yell at me and you think that settles it" (80). Towards the end of the play, when Kate tells Joe, "You're so foolish. Larry was your son too, wasn't he? You know he'd never tell you do 
this", Joe, looking at the letter in his hand says, "then what is this if it isn't telling me? Sure he was my son. But I think to him they were all my sons. And I guess they were. I guess they were. I'll be right down” (89).

Keller realizes that he has to pay for his part and suicide becomes inevitable. Keller discovers the truth of Larry's death, finally accepts his responsibility for the crime and kills himself. Further, it is Kate's exhortation to Chris. Joe feels empathetic, and the end turns out to be pathetic. Inside the house, Keller shoots himself, "which produces a highly theatrical curtain without making the change of heart theatrically valid" (Hayman 26). All My Sons is "a play of limited craftsmanship which derived its interest from a contemporary issue and which in its treatment reveals the influence of Ibsen as it resolves the conflict between social responsibility and personal interest" (Couchman 11).

Throughout the play, Kate seems to be a concerned wife. Miller wishes to emphasize the qualities of a good mother: love, devotion and sacrifice. Kate's effort to protect Joe fails in Act-III. Efforts continue when Kate pleads Chris to spare his father. Joe decided his ultimate journey (death) alone without the help of the women counterpart who loved him. Kate lost both his son and husband. The woman who lived her whole life with the false dream of her husband suffered because of it. The chief sufferer in the drama of success and war is the woman. "Miller has presented Kate as twice a victim-victim of war because it claimed her son and victim of her husband's manipulation in the service of his dreams of success in which she has no part and of which she doesn't approve"(Abraham 172).

The role of Ann is also vital in the play. Ann, who was brought up in the next door of Joe, is Steve's daughter and "Larry's girl" (72). It is she, who has the critical piece of information about Larry's death. In this context, she is a significant character in the play: "A close reading of the text will yield next to nothing about Ann's background, traits and social attitude. But perhaps these characters can be discussed with more profit in relation to the theme of the play" (Murray 17). The cause of Ann's arrival and her Brother George's visit on the same day also seen mysterious. "(...$)$ the romance between Chris and Ann doesn't encourage close scrutiny. There is something vague, even a little "mystical," about the coming together of the two lovers that suggests love less than manipulation" (Murray 9). Ann feels Chris is behind the bar of obligation he owes to his father. Ann suddenly appears and forces Kate to read the letter written by Larry just before his death. Ann simply acts as an "informer" of Joe's guilt, the information that led to a great catastrophe.

The relation of Chris and Ann in the play becomes secondary when the dramatic emphasis shifts to Chris, Joe, and their confrontation. "Moreover instead of being dramatically realized individuals, Kate Keller and Ann Denver are too patently related to the development of the plot. Thus, when their conflict is over, Chris is subverted, they simply fade away and remain only peripherally involved in the situation that they helped to elicit. Similarly, the whole problem of Kate's obsessive delusions about her dead son, which is apparently crucial to the first half of the play, is resolved so rapidly and neatly that one cannot help but suspect the depth of her original dilemma" (Nelson 93).

Chris's intention of marrying Ann is a clear indication that there is a world beyond business world. He does not mind to "grub the money" (15) but must have a purpose. "...If I have to grub the money all day long at least at evening I want it beautiful. I want a family. I want some kids. I want to build something I can give myself to. Ann is in the middle of it. Now...where do I find it'?" (Act-1, 15) For Chris, beyond the business and professional life, there is also another life which is intimate and private, the source of inspiration for his work. Chris finally declares his love for Ann, which is reciprocated. Ann has been waiting for this day for a long time.

Chris: Ann I love you. I love you a great deal.[finally] I love you.[she waits] I have no imagination...that's all I know to tell you.[Ann is waiting, ready] I'm embarrassing you. I didn't want to tell it to you here. I wanted some place we'd never been; a place where we'd be brand new to each other....You feel it's wrong here, don't you? This yard, this chair? I want you to be ready for me. I don't want to win you away from anything.

Ann [putting her arms around him]: Oh, Chris, I've been ready a long, long time! (Act-1, 34-35)

"In All My Sons, the love between the generations is both more prominent and more convincing than the love between Chris and Ann, which is rather timely written, or than Chris's love for the soldiers who served under him in the war, which is rather over-written" (Hayman 20). Ann is desperate to marry Chris .She wants to marry Chris and seeks social security in the name of marriage. But the obstacle is Kate's unreasonable conviction that Larry will return someday and her firm view that Ann is Larry's girl. For the first time they express their love to each other as if the expression of their love was long awaited and was waiting for an opportunity. 
Ann: I was waiting for you, Chris. Till then you never wrote. And when you did, what did you say? You sure can be ambiguous, you know.

Chris: (looks towards house, then at her, trembling) Give me a kiss, Ann, Give me a (They kiss). God I kissed you Annie. I kissed Annie. How long I've been waiting to kiss you!

Ann: I'll never forgive you. Why did you wait all these years? All I've done to sit and wonder if I was crazy thinking of you" (Act-1, 35).

Towards the end of Act 3, Ann asks Kate to accept the truth about Larry's death so that Chris would be free to marry Ann and not feel guilty about it. "...You made Chris feel guilty with me. Whether you wanted it or not, you've crippled him in front of me."(82) However, Chris escapes out of the situation declaring his intention of going away forever, without her. "I've been so lonely Kate... I can't leave here alone again. (84) ...Where do I go? I have nowhere to go," (85) says Ann towards the end of the play.

Ann's conversation with Sue seems to be superficial in the play. She finds unusual of Ann to marry Chris. Sue seems to be a very practical woman. She hates Chris's idealism. Sue along with other neighbors believe in Joe's guilt and cannot tolerate his freedom at the expense of Steeve Deever. Sue, Dr. Jim's wife, feels unusual of Ann being tied to Chris, “...It's romantic...it's very unusual to me, marrying the brother of your sweetheart." To which Ann replies... I don't know, I think it's mostly that whenever I need somebody to tell me the truth I've always thought of Chris. When he tells you something, you know it's so. He relaxes me" (45).

Sue Bayliss is an utterly cynical woman. Her ambitions are material wealth and social acceptance. She is not aware of the moral values that her husband shares with Chris. Sue is quite right in her own way because modern life is full of compromises where you have to put a mask to adjust to the particular situation. From her conversation with Ann, it is quite clear that Sue does not want Chris to encourage her husband with his "phoney idealism." Lydia was George's love interest before the war; after he went away, she married Frank and they quickly had three children. She is a model of peaceful domesticity and lends a much-needed cheerful air to several moments of the play. When Lydia emerges, her past relationship with George is then revealed. Lydia has had three children and shows George the life on which he missed out while he was serving in World War II.

The dominant theme in All My Sons is hypocrisy. Firstly, Jim Bayliss's wife, Sue, believes that Chris is a hypocrite as he talks about higher values, while at the same time supports Joe (his father) who is guilty. Secondly, Kate knows the reality about Larry and his death, yet behaves like a schizophrenic so that Joe does not go to jail. Then Chris, by trying to get Ann, hurts his mother by trying to break her illusion that Larry is alive. The family in the play is presented to us as something difficult, treacherous, and full of emotional stress. The relationship between everyone is strained and even the deep bonds of the family members are broken by realization of the wrong doings.

At one point, Kate couldn't get a grip on her life to the son falling in love Kate's denial of Larry's death makes her a trademark of Miller's work, and annoying female character. She is overbearing and at times a nag. She is even the creator of the conflict between Chris and Ann, Kate is the real protagonist of the play. She plays a very important role although she is not noticed so much in the play. Right from Act I, the significance of the broken tree is shown. Losing a son in the war was not uncommon in that era, but this shows Kate's inner strength. She is portrayed as weak and fragile but is hindsight she is a solid character. She has lived with the knowledge of her husband's crime and the thought that if her son is dead, it is ultimately her husband's doing. Her final word "Don't dear. Don't take it on yourself. Forget now. Live," (90) lies Kate Keller's both strength and weakness. Mainly for Chris's sake, she remains strong. It is Joe not Kate, who goes for a suicide. Ultimately, she stays.

\section{Work Cited}

[1]. Abraham, Taisha."New Orientations, Feminist Theory and Modern Drama." An Anthology of Recent Criticism. Pencraft International, Delhi, 1998

[2]. Brantley, Ben.Theater Review: All My Sons.: The New York Times. October 17, 2008.

[3]. Couchman, Gordon W."Arthur Miller Tragedy of Babbill.” Educational Theatre Journal. VII, 1955.

[4]. Hayman, Ronald.Arthur Miller. Contemporary Playwright Series. London: Heinemann, 1970.Miller, Arthur.

[5]. Timebends: A Life. New York: Grove Press, 1987.

[6]. ---Collected Plays with an Introduction. New York: The Viking Press, 1957.

[7]. Murray, Edward.Arthur Miller Dramatist. New York: The Viking Press, 1967

[8]. Nelson, Benjamin. Arthur Miller. Portrait of a Playwright. Peter Owen: London, 1970.

[9]. Schlueter, June.Feminist Reading of Modern American Drama. London: Associated University Press, 1989. 